\title{
THE EFFECT OF USING ONLINE READING RESOURCES TOWARDS STUDENTS' READING COMPREHENSION IN EXTENSIVE READING CLASS
}

\author{
Estika Satriani \\ Islamic University of Riau \\ email: estikasatriani@edu.uir.ac.id
}

\begin{abstract}
The students at the Second Semester of English Study Program of FKIPUIR Pekanbaru have problem in reading comprehension. The aim of this research is to find out whether Online Reading Resources has significant effect towards students' reading comprehension in extensive reading class. The design of the research was experimental research which focused on quantitative approach. The participants of the research were the second semester students of English Study Program of FKIP-UIR Pekanbaru. There are two classes as the samples of this research; experimental group and control group. Each of the group consisted of 31 students. The instruments of this research was reading test. Experimental group was provided with pre-test, treatment, and post-test. Meanwhile control group only given pre-test, and post-test. The finding showed that the mean score in pretest was 57.25 and post test was 78.07, the improvement was 20.8 for experimental group. Meanwhile for control group in pre-test, the students got the mean score 58.07, and in post-test got 64.67, improvement was 6.61. It could be stated that there is significant effect of online reading resources after getting treatment. In calculation of analysis $t_{t}(t$ table) on the level of significant $5 \%$ found 0.361 , and $t_{o}$ was 7.1. It could be seen a comparison was $7.1>0.361$ or $\left(t_{o}>t_{t}\right)$. It means that the null hypothesis is rejected and alternative hypothesis is accepted. It can be stated there is a significant effect of students' reading comprehension in extensive reading class after using online reading resource in teaching and learning reading at the second semester of English Study program FKIP-UIR Pekanbaru.
\end{abstract}

Keywords: Online Reading Resources, Reading Comprehension

\section{PENGARUH MENGGUNAKAN SUMBER BACAAN ONLINE TERHADAP PEMAHAMAN MEMBACA SISWA DI KELAS EXTENSIVE READING}

\begin{abstract}
Abstrak
Mahasiswa semester dua program studi Bahasa Inggris FKIP-UIR Pekanbaru pada kelas extensive reading menemukan kesulitan dalam memahami bacaan. Tujuan penelitian ini adalah untuk mengetahui apakah sumber-sumber bacaan online berpengaruh pada pemahaman membaca mahasiswa semester dua program studi Bahasa Inggris FKIP-UIR Pekanbaru.Penelitian ini menggunakan metode eksperimen yang fokus pada pendekatan kuantitatif. Partisipant penelitian
\end{abstract}


ini adalah mahasiswa semester dua program studi Bahasa Inggris FKIP-UIR Pekanbaru yang terdiri dari dua kelas yaitu kelas eksperimen dan kelas kontrol. Masing-masing kelas terdiri dari 31 siswa. Untuk memperoleh data pada penelitian ini, peneliti menggunakan tes sebagai alat (instrument) dengan memberikan 10 pertanyaan dalam bentuk essay. Pada kelas eksperimen diberikan test awal, perlakuan, dan tes akhir. Sedangkan untuk kelas kontrol hanya diberikan tes awal dan tes akhir tanpa ada perlakuan (tidak menggunakan sumber bacaan online dalam belajar reading). Berdasarkan hasil analisis data dari penelitian ini, didapatkan bahwa nilai awal mahasiswa kelas eksperimen adalah 57.25 dan nilai akhir nya adalah 78.07. disini bisa dilihat bahwa ada peningkatan nilai sebesar 20.8untuk eksperiment kelas. Sedangkan nilai awal kelas kontrol adalah 58.07 dan nilai akhirnya yaitu 64.67, tidak terlihat peningkatan yang siknifikan pada kelas kontrol. Dari data tersebut dapat dikatakan bahwa ada efek positif dari sumber bacaan online terhadap pemahaman membaca mahasiswa. Hasil analisis perhitungan $t_{t}\left(t\right.$ table) pada level 0.05 ditemukan 0.361 dan $t_{o}$ adalah 7.1. dilihat dari data yang ditampilkan dapat dinyatakan sebuah perbandingan bahwa 7.1 $>0.361$ atau $\left(\mathrm{t}_{\mathrm{o}}>\mathrm{t}_{\mathrm{t}}\right)$ yang berarti bahwa null hypothesis ditolak dan alternatif hypothesis diterima. Berdasarkan keterangan hasil analisis data diatas dapat disimpulkan bahwa ada efek yang siknifikan dari sumber bacaan oline terhadap pemahaman membaca mahasiswa semester dua program studi Bahasa Inggris FKIP-UIR Pekanbaru pada kelas Extensive Reading.

Kata Kunci : Sumber Bacaan Online, Pemahaman Membaca

\section{INTRODUCTION}

Reading of foreign language as a source of information is one of the main goals of teaching and learning in education world. The purpose of reading is to get information and new things. Grabe (2009) states that reading in academic setting is divided into six major purposes, there are reading to search for information, reading for quick understanding, reading to learn, reading to integrate information, reading to evaluate, critique, and use information, and reading for general comprehension in many cases, reading for interest or reading to entertain. It can be acquired from books, magazines, and even internet is a great learning tool which

J-SHMIC, Vol 4, No 2, August 2017 require the ability to read and understand what is read.

To get the information from the reading text, the reader need to ability in comprehending the text that they read. According to Catherine Snow (2002:11) Reading comprehension as the process of simultaneously extracting and constructing meaning through interaction and involvement with written language. Comprehension entails three elements: the reader who is doing the comprehending, the text that is to be comprehended, and the activity in which comprehension is a part.

Grabe (2010:28) the automatic process in reading is the outcome of thousands hours of meaningful input. It

The Effect of Using Online Reading Resources Towards Students' Reading Comprehension in Extensive Reading Class. 
is meant that most of foreign language readers spend many times and think that reading is difficult and feel frustrating when they have large time to read and to get the meaning of the text that they read.

Besides that, King and Stanley (1989:8) explain the skill in reading comprehension has five aspects to find specific detail, finding main idea, finding the meaning of vocabulary in the context, identifying reference, and making inference. In other words, in reading comprehension the reader should get the meaning from written words, sentences and texts as whole.

Considering the important of reading, it is crucial which reading should be given the greatest attention in any level of education, especially in university level. In second semester of English Study Program of FKIP-UIR, reading class is extensive reading, it has 150 minutes to every class in a week. In those classes, students work in short text with close guidance from the teachers. Teachers design reading class in such a way that they need to allocate time to activate students' background knowledge, to ask students to read the text, and they also need time for several other activities related to comprehension, vocabulary, grammar and others.

Based on the researcher experience when thought reading in her class, she found that the students spent their time to read a reading text was not more than forty minutes in a week. The students read the text when they needed to write the task; even they copied their friends work. They did not enjoy reading the book that the teacher given. In practice reading class, the students also still read slowly and had difficult to get the information from the reading text. The main reason of the problem above is the students do not have enough time to prepare extensive reading activities due to the limited amount of reading resources available. Nevertheless, extensive reading should give contribute in developing of variant of reading material, reading speed, reading habit, and general understanding.

One of direct implication for teaching reading is giving the students an opportunity to read not only in the classroom but also outside of the classroom. It is also necessary that students are provided with activities or task to read outside classroom as a means of practice to develop reading abilities. Students should also be encourage to read as often as possible extensively and, Harmer (2007:101).

Online reading resources can facilitate students to be better readers and to be fluent readers, since it provides considerable grade reading resources followed with several activities accompanied with individualize feedback on students' performance. When reading resources in the library is limited and Wi-Fi facility is available around campus, it is possible for the lecturer to use online reading resources by using internet as mean to help students to be better readers.

Nowadays, internet also has become an inseparable part of the life of most university students. They can access internet through cellular phone or wireless facility around campus area. Internet is a source of potential benefit in language classroom provided that availability of free teaching and learning resources that can be used in extensive reading class.

Extensive reading is the reading class subject in the second semester of English Study Program. Brown (2001:302) says that extensive reading 
involves reading of large quantities of material, directly and fluently. It may include reading simply or pleasure or reading technical, scientific reading or professional material. Similarly, Richard and Renandya (2002:300) describe that the students don't have enough time to prepare and extensive reading activities due to the limited amount of reading resources available.

To expand teaching and learning process, the lecturer use online reading resources on extensive reading class through internet. Extensive reading class through internet invites learners to read online. Reading online consists of reading texts from a portion of a computer screen.

Online is one condition of being connected to a network of computers or other devices. The term is basically used to describe someone who is currently connected to the internet. According to Guo (2012) contended that authentic materials from the internet are highly valuable because those materials can generate greater interest among teacher and students than traditionally structured materials do. Another reason for using internet resources is that the internet can provide readers easy access to a large quantity of reading materials.

Online reading resources are reading materials that the reader find by online, it can be an online newspaper, magazine, or television, website such as NBC or CNN, and Peer-reviewed journals, and Web Pages. Forums and blogs are also online reading resources. $\mathrm{Li}$ and Hart in Richard and Renandya (2002:362) state that when used online reading resources in language class, it has a number of features that are suitable for growing proficiency in the language It provide a rich database of authentic materials, offers tools for interactive learning, provide context for collaborative material development, it is conducive to language learning and the material stored in the Web can reach a large audience with relatively low cost.

To apply online reading resources in teaching and learning reading on extensive reading class, Tamar Mikeladze (2014) explain some sections;

The first section, students go to class website. Ask students to choose a story that they are interested to read. Make sure that all students can open the site to read the story. Ask students to start reading individually and silently in the class. Then remind students that they can change the reading topics, stories, and/or articles. After reading the students write the author's name and the title of the book. This section helps them to pay attention to the significance of the title and it will help them keep their worksheet organized. Students should keep a record of the material that they have read.

In the second and third sections the students write the number of pages in the reading text and the amount of time they spent on reading the text. This data enables the students to monitor their progress. They can compare the speed that they read a book, article, journal, short story to previous one. The students can also use this section to monitor the time that they have worked on extensive reading lessons throughout the course.

In the fourth section the students list and describe briefly the characters. This section, as well as the fourth and the fifth sections, develops a reading strategy, scanning, in readers. Scanning is a technique often used when looking for specific information, for key words or ideas. Scanning involves moving eyes quickly down the page seeking 
specific words and phrases (Nuttall, 2000, p.49).

In the fifth section the students write about the significance of the reading resources and their further comments. After reading, students usually remain under the impression of the reading resources. They want to express their ideas, judgments and emotions after reading. They often complete this section with zeal. In this section students often express their appreciation of the author's writing style; however, sometimes students criticize the author and they write their preferred ending to the story.

In the sixth section the students discuss those few new words and expressions that they found important and interesting for them. Students especially like this section because they can demonstrate what they have learned. The students can discuss words 'meanings in their oral presentation.

In the seventh section the students rate the reading resources. This activity is easy for the students.

In the eighth section the students write the summary. Students summarize the plot of the reading resources briefly. This activity helps students to concentrate on the main idea of the book. According to Hatzitheodorou (2008: 61).

In the ninth section the students analyze the difficulty of the reading material.

The students use this steps to fill the reading log. Reading log used by reseacher to know the students progres in extensive reading by using online reading resources.

\section{METHOD}

The design of this research was experimental research which was conducted at English Study Program of
FKIP-UIR Pekanbaru. There are two group as sample here; experimental group and control group. The research conducted on February to May 2017.

According to (Hatch and Farhady, 1982), the experimental research is a method of research that can truly test hypothesis concerning with cause and effect relation in the experimental research.

There are two variables here: online reading resources are independent variable, while the extensive reading class is dependent variable. Therefore experimental class provided pre-test, treatment, and post - test, meanwhile control group given only pre-test and post test.

Pre-test were given before getting a treatment for experimental and control group. The purpose of this kind of the test is to measure the sample respondents' reading comprehension through online reading resources. Pretest was conducted in first meeting. The test consists of 10 items essay questions. For this research, the reading passages and questions are selected from internet. The test classified based on indicators of reading comprehension, they are finding main idea, finding details information, and building vocabulary, reference, and inference.

The writer gave treatment in four meetings. The treatment was given only to experimental group. It was design in the lesson plan. Treatment designed in four meetings. Every meeting contained teaching and learning reading comprehension by using online reading resources on extensive reading class. The following class activities:

\section{In the first meeting}

1. The researcher asked students some questions about reading text to explore their background knowledge.

The Effect of Using Online Reading Resources Towards Students' Reading Comprehension in Extensive Reading Class. 
2. Introduced the lesson.

3. The researcher asked students to go to class website at http://dntrung.weebly.com/extensivereading.html. (The reading links to internet)

4. The researcher asked students to choose a story that their interest to read.

5. The researcher made sure that all students can open the site to read the story by around the class and asked the students one by one.

6 . The researcher asked students to start reading individually and silently in class.

7. The researcher reminded the students that they can change the reading topics, stories, and/or articles.

8. In the last 5 minutes, the researcher asked students to recommend their favorite story to the whole class by posting their link and comments http://dntrung. weebly.com/blog.html

9. The researcher asked students to filled reading log.

10. The reseacher encouraged students to further browse suggested reading links on the website at home.

11.In the end of the class, the researcher gave the students task.

\section{In the second and third meeting}

1. The researcher asked students to share useful websites that can be used for extensive reading.

2. The researcher asked students to briefly talk to the class about the websites they have found.

3. The researcher asked students to work individually and silently.

4. The researcher made sure that students can access the sites.

5. The researcher asked students to choose one of the topics that they are interested to read.
6. The researcher told to students that they can change the topic or the story they are reading if it is not interesting.

7. The researcher asked students to filled reading log after reading.

8. The researcher gave comments to students' work.

9. The reseacher asked students to continue to search for useful links for extensive reading at home.

\section{The fourth meeting}

1. The reseacher gave the students some questions about their reading activity at home.

2. the reseacher asked all student to present their work.

3. Control "Questions and Answers" activity after each presentation. Each student will have 2 minutes to answer the questions from the audience.

4. Give comments on students work, the students' participation in class website

5. Thank the whole class for their great work on the extensive reading class.

After giving the treatment, the reseacher gave post-test for both experimental and control group. It aimed to know whether any significant effect online reading resources toward extensive reading class. The test consists of 10 items essay questions that relevant with indicators of reading comprehension; building vocabulary, identify mean idea, and finding detail information, reference, and inference.

The data obtained from the experimental and control group. Data collected by giving pre-test and post test, then the researcher analyzed the data and compared the mean score of control group and experimental group by using the t-test formula by (Sudijono 2009:81)

The Effect of Using Online Reading Resources Towards Students' Reading Comprehension in Extensive Reading Class. 
1. The score of students

To score of students was calculated by applying the following formula:

Score $=\frac{\text { right }}{\text { item }} \times 100$

2. Mean Score

$\mathrm{M}_{\mathrm{x}}=\frac{\Sigma x}{N}$

3. Difference (D) and $\Sigma \mathrm{D}$

The difference between variable 1 (pre test of $\mathrm{X}$ ) and variable II (post test $\mathrm{Y}$ ), so the Difference (D)

4. Mean of Difference (MD)

$$
\mathrm{MD}=\frac{\Sigma \mathrm{D}}{\mathrm{N}}
$$

5. Amount of D quadrate $\left(D^{2}\right)$

Next quadrate each $\mathrm{D}$ and after that find $\mathrm{D}^{2}$, sum up all of $\mathrm{D}^{2}$ get amount of $\mathrm{D}^{2}$

$\left(\Sigma \mathrm{D}^{2}\right)$

6. Standard Deviation $\left(\mathrm{SD}_{\mathrm{D}}\right)$

$$
\mathrm{SD}_{\mathrm{D}}=\sqrt{\frac{\Sigma \mathrm{D}^{2}}{\mathrm{~N}}-\left(\frac{\Sigma \mathrm{D}}{N}\right)^{2}}
$$

7. Standard Error of Mean Difference $\left(\mathrm{SE}_{\mathrm{MD}}\right.$

$\mathrm{SE}_{\mathrm{MD}}=\frac{\mathrm{SDD}}{\sqrt{N-1}}$

8. T-Test $\left(\mathrm{t}_{\mathrm{o}}\right)$

t-test $\left(\mathrm{t}_{\mathrm{o}}\right)$ can get by this formula: $\mathrm{t}_{\mathrm{o}}$ $=\frac{M D}{\text { SEMD }}$

8. T-test hypothesis

After getting of T-test found the degree of freedom ( $\mathrm{df}$ or $\mathrm{db}$ ) Formula: Df or $\mathrm{db}=\mathrm{N}-1$

Based on the value of degrees of freedom, the researcher can find value of $t$ in t-table with the significance $5 \%$ and $1 \%$.

$\mathrm{t}_{\mathrm{o}} \geq \mathrm{t}_{\mathrm{t}}=\mathrm{H}_{\mathrm{o}}$ is rejected, $\mathrm{H}_{\mathrm{a}}$ is accepted.

$t_{0}<t_{t}=H_{o}$ is is accepted, $H_{a}$ rejected.

\section{FINDING AND DICUSSION}

The data description of this research is intended to present the data

J-SHMIC, Vol 4, No 2, August 2017 found in the research on "the effect of utilization online reading resources toward students' reading comprehensive on extensive reading class".

Pre-test was conducted by the researcher for experimental group and control group. Pre-test conducted to find out the students comprehension in reading text before given treatment by using online reading resources. The students' pre test score showed as the following table:

Table 4.1 the score of students' reading comprehension in pre-test For Control Group

\begin{tabular}{|c|c|c|c|c|c|c|}
\hline Des & V & M I & D & R & I & Score \\
\hline Sum & 350 & 300 & 455 & 430 & 265 & 1800 \\
\hline Mean & 11.29 & 9.68 & 14.68 & 13.87 & 8.55 & 58.07 \\
\hline
\end{tabular}

Table 4.1 showed that students' mean scores in pre-test were building vocabulary was 350 (11.29), Main Idea was 300 (9.68), Detail Information was 455 (14.68), meanwhile for Reference was 430 (13.87), and Inference was 265 (8.55). Total score for five indicators from 31 students were 1800 or (58.07). it can be seen in the following figure:

Figure 4.1 the score of students' reading comprehension in pre-test For Control Group

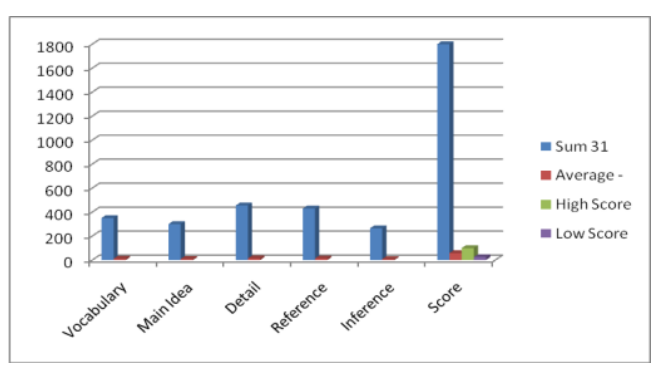

Table 4.2 the score of students' reading comprehension in pre-test For Experimental Group

The Effect of Using Online Reading Resources Towards Students' Reading Comprehension in Extensive Reading Class. 


\begin{tabular}{|c|c|c|c|c|c|c|}
\hline D & V & M I & D & R & I & Sc \\
\hline Sum & 400 & 260 & 440 & 445 & 230 & 1775 \\
\hline Mean & 12.9 & 8.39 & 14.19 & 14.35 & 7.42 & 57.25 \\
\hline
\end{tabular}

Table 4.2 showed that students' mean scores in pre-test were building vocabulary was 400 (12.9), Main Idea was 260 (8.39), Detail Information was 440 (14.19), meanwhile for reference was 445 (14.35), and inference was (7.42). Total score for five indicators from 31 students were 1775 or (57.25). It can be seen by figure below:

Figure 4.2 the score of students' reading comprehension in pre-test For Experimental Group

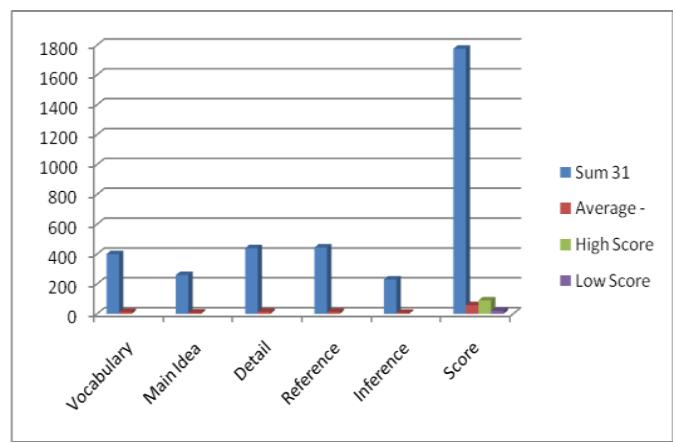

Based on the table and figure above both experiment and control group can be concluded that experiment group and control group practically have the same capability in comprehending the text based on the five indicators of the test that have given by researcher. It indicated that they have low in comprehending of the text, their scores were still under KKM that was 75 .

After analyzing pre-test, the researcher gave the students treatment in four meeting which teaching and learning reading process by using online reading resources.

Since the researcher gave
treatment for the students in

J-SHMIC, Vol 4, No 2, August 2017 experimental group, then the researcher gave the students post-test to know whether online reading resources could give significant effect to students' reading comprehension. The result of students post-test could be seen in the following tables:

Table 4.3 the score of students' reading comprehension in Post-test For Experimental Group after using online reading resources

\begin{tabular}{|c|c|c|c|c|c|c|}
\hline Des & V & M I & D & R & I & Score \\
\hline Sum & 500 & 410 & 550 & 570 & 390 & 2420 \\
\hline Mean & 16.13 & 13.23 & 17.74 & 18.39 & 12.58 & 78.07 \\
\hline
\end{tabular}

Table 4.3 showed that students' mean scores in post-test of experiment group were in building vocabulary was 500 (16.13), Main Idea was 410 (13.23), Detail Information was 550 (17.74), meanwhile for reference was 570 (18.39), and for inference was 390 (12.58). Total score for five indicators from 31 students were 2420 or (78.07). It can be proved by the following figure:

Figure 4.3 the score of students' reading comprehension in post-test For Experimental Group

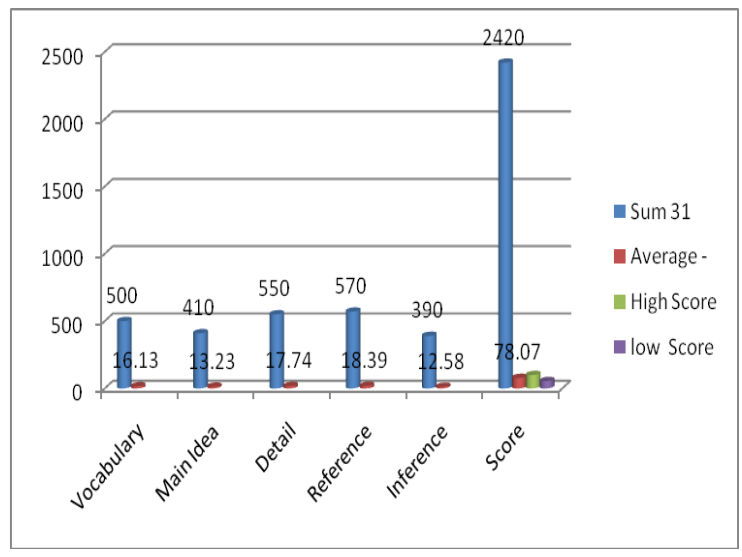

Table 4.4 the score of students' reading comprehension in post-test For Control Group

The Effect of Using Online Reading Resources Towards Students' Reading Comprehension in Extensive Reading Class. 


\begin{tabular}{|l|l|l|l|l|l|l|}
\hline Des & \multicolumn{1}{|c|}{ V } & \multicolumn{1}{c|}{ M I } & \multicolumn{1}{c|}{ D } & \multicolumn{1}{c|}{ R } & \multicolumn{1}{c|}{ I } & Score \\
\hline Sum & 405 & 330 & 475 & 480 & 315 & 2005 \\
\hline $\mathrm{M}$ & 13.06 & 10.65 & 15.32 & 15.48 & 10.16 & 64.67 \\
\hline
\end{tabular}

Table 4.4 showed that students' mean scores in pre-test of control group were building vocabulary was 405 (13.06), Main Idea was 330 (10.65), Detail Information was 475 or (15.32), meanwhile for reference was 480 (15.48), and for inference was 315 (10.16) . Total score for five indicators from 31 students were 2005 or (64.67). It can be proved by the following figure:

Figure 4.4 the score of students' reading comprehension in post-test For Control Group

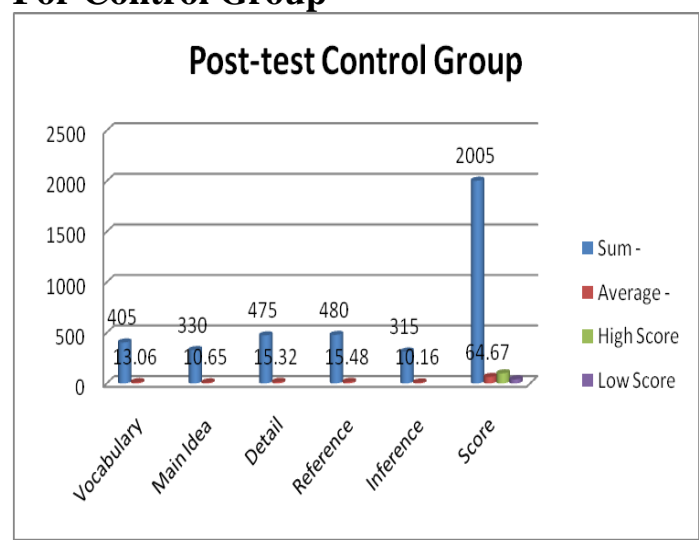

The data above showed that for the experimental class average 78.07, the score is much higher than the control class which average score only 64,67. Descriptively, it shows that the experiment can be declared as successful experiment. It can be stated that students who given a treatment by online reading resources in learning reading show a higher score than a group of students whose given only conventional way.

To know the improvement score between experiment group and control group in pre-test and post-test, the researcher made comparison the result or mean score between pretest and post

J-SHMIC, Vol 4, No 2, August 2017 test, it can be seen in the following Figure:

Figure 4.5 the Improvement score of Students' Reading Comprehension in Pre-Test and Post Test for experimental group

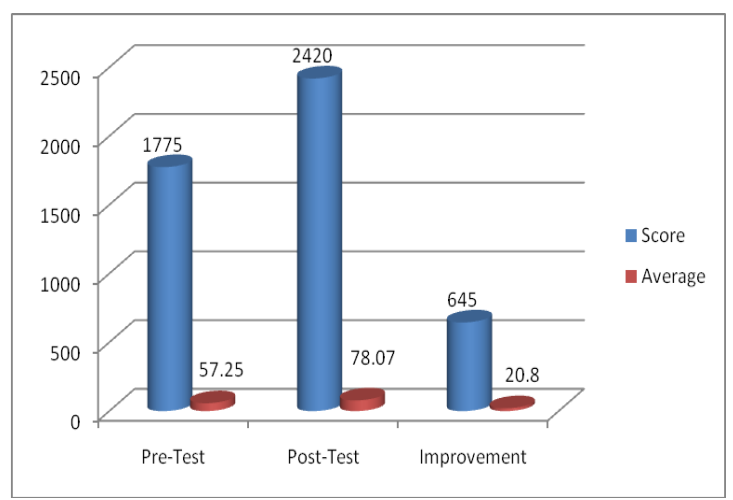

Figure 4.6 the Improvement score of Students' Reading Comprehension in Pre-Test and Post Test for control group

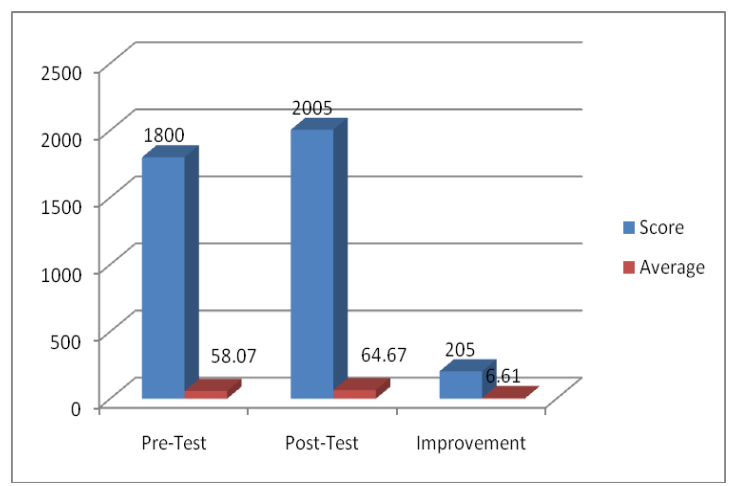

The data in the figure 4.5 and figure 4.6 showed that the mean score of experimental group was 20.8 and control group was 6.61 the improvement was 14.19 .

After showing the data in pretest and post test, the researcher analyzed the data. It was done to answer the formulation of the research and to know the difference of improvement

The Effect of Using Online Reading Resources Towards Students' Reading Comprehension in Extensive Reading Class. 
between pre-test and post test score after the researcher did the treatment by using online reading resources as a material of teaching and learning reading. In the following was the table of students' individual score in pre test and post test.

\section{Data Analysis}

Table 4.5 The Students' Individual Score in Pre Test and Post Test.

\begin{tabular}{|c|c|c|c|c|}
\hline Sample & $\begin{array}{l}\text { Pre- } \\
\text { test }\end{array}$ & $\begin{array}{c}\text { Post- } \\
\text { test }\end{array}$ & $\mathrm{D}(\mathrm{X}-\mathrm{Y})$ & D2 \\
\hline 1 & 45 & 80 & -35 & 1225 \\
\hline 2 & 45 & 80 & -35 & 1225 \\
\hline 3 & 80 & 85 & -5 & 25 \\
\hline 4 & 45 & 70 & -25 & 625 \\
\hline 5 & 40 & 55 & -15 & 225 \\
\hline 6 & 55 & 55 & 0 & 0 \\
\hline 7 & 60 & 70 & -10 & 100 \\
\hline 8 & 70 & 85 & -15 & 225 \\
\hline 9 & 70 & 100 & -30 & 900 \\
\hline 10 & 50 & 65 & -15 & 225 \\
\hline 11 & 35 & 60 & -25 & 625 \\
\hline 12 & 65 & 70 & -5 & 25 \\
\hline 13 & 45 & 95 & -50 & 2500 \\
\hline 14 & 70 & 100 & -30 & 900 \\
\hline 15 & 40 & 60 & -20 & 400 \\
\hline 16 & 20 & 85 & -65 & 4225 \\
\hline 17 & 90 & 100 & -10 & 100 \\
\hline 18 & 75 & 70 & 5 & 25 \\
\hline 19 & 45 & 80 & -35 & 1225 \\
\hline 20 & 65 & 65 & 0 & 0 \\
\hline 21 & 80 & 75 & -5 & 25 \\
\hline 22 & 70 & 80 & -10 & 100 \\
\hline 23 & 75 & 85 & -10 & 100 \\
\hline 24 & 80 & 90 & -10 & 100 \\
\hline 25 & 35 & 70 & -35 & 1225 \\
\hline 26 & 25 & 80 & -55 & 3025 \\
\hline 27 & 50 & 80 & -30 & 900 \\
\hline 28 & 60 & 80 & -20 & 400 \\
\hline 29 & 40 & 60 & -20 & 400 \\
\hline 30 & 80 & 100 & -20 & 400 \\
\hline 31 & 70 & 90 & -20 & 400 \\
\hline & 1775 & 2420 & \multirow[t]{2}{*}{-655} & \multirow[t]{2}{*}{21875} \\
\hline & 57.25 & 78.07 & & \\
\hline
\end{tabular}

$\sum D=-655$

$\sum D^{2}=21875$

$$
\begin{aligned}
& \mathrm{SD}_{\mathrm{D}}=\sqrt{\frac{\sum D^{2}}{N}-\frac{(\Sigma D)^{2}}{N}} \\
& \sqrt{\frac{21875}{31}+\left(\frac{-655}{31}\right)^{2}} \\
& \sqrt{705.65-446.44}=\sqrt{259.21} \\
& =16.1 \\
& \mathrm{SE}_{\mathrm{MD}}=\frac{\mathrm{SDD}}{\sqrt{N-1}}=\frac{16.1}{\sqrt{N-1}}=\frac{16.1}{\sqrt{30}} \\
& =\frac{16.1}{5.47} \\
& =2.94 \\
& \mathrm{t}_{0}=\frac{M D}{\operatorname{SEMD}}=\frac{-20.8}{2.94}=-7.1
\end{aligned}
$$

(The minus sign was not the sign in aljabar, but it showed by the difference. In this case, there was difference 7.1) Degree Freedom $(d f)=n-1(D f=31-1=$ 30

$\mathrm{T}_{\mathrm{t}} \mathrm{T}$ table) on the level of significant $5 \%$ was 0.361 , while $t_{0}$ was 7.1. So, it could be concluded a comparison: $7.1>0.361$ (it means that $\mathrm{t}_{\mathrm{o}}>\mathrm{t}_{\mathrm{t}}$ ).

\section{Hypothesis Testing}

From the calculation of the analysis, data,it was found that $t_{t}$ was 0.361 at the level of significant $5 \%$ was smaller than $t_{0}$ was 7.1. In the other word, $t_{o}$ was bigger then $t_{t}$ in the level significant $5 \%$. It meant that the null hypothesis was rejected and alternative hypothesis was accepted. It can be stated there was a significant effect of students' reading comprehension after using online reading resources as a media in teaching and learning reading process at the second semester of English Study program FKIP-UIR Pekanbaru. 


\section{CONCLUSION}

Online reading resources can affect students' reading comprehension in extensive reading class at the second semester of English Study Program of FKIP-UIR Pekanbaru. $T_{t}$ (t table) in the level of significant $5 \%$ is 0.361 meanwhil $t_{o}$ is 7.1. So, it could be concluded a comparison: $7.1>0.361$ or $\mathrm{t}_{\mathrm{o}}>\mathrm{t}_{\mathrm{t}}$. The null hypothesis was rejected and the alternative hypothesis was accepted. As the result, there was a significant effect of using online reading resources toward students' reading comprehension on extensive reading class at the second semester of English Study Program of FKIP-UIR Pekanbaru.

Students also become more active and motivated in learning process. It showed from the score of the students. In the data analysis, the base average score is 57.25, it is in level (poor), after giving treatment by using online reading resources increase to be 78.07 (good). The score in post test reach over KKM.

\section{REFERENCES}

Guo, S 2012. Using Authentic Materials for Extensive Reading to Promote English prociency. In English Language Teaching.

Grabe, William. 2009. Reading in Second Language: Moving from theory to Practice. Cambridge: Cambridge University Press.

Grabe, W. (2010). Fluency in readin Thirty-five years later. Reading in a Foreign Language

Brown H. Douglas. 2001. Teaching by Principles. An Interactive Approach to Language Pedagogy. New York : Longman.
Harmer, Jeremy. 2007. How to Teach English Cambridge: Cambridge University Press

Hatch, E. \& H. Fahrady. 1982. Research Desain and Statistics. London: Newbury House.

King and Stanley. 1989. Building Skill for the TOEFL. Jakarta: printed and bound by Binarupa Aksara.

Mikeladze, $\mathrm{T}$ 2011. Implementing Extensive Reading in Georgian University. Tblisi:University

Nuttall, C. (2000). Teaching reading skills in a foreign language. Hong Kong. Macmillan Publishers Limited.

Richard, Jack C. \& Renandya Willy. A. 2000. Methodology on Language Teaching. An Ontology of Current Practice.Cambridge:Cambridge University. Presshttp://kominfo.go.id/index.p hp/content/detail/3980/Kemkomfo Sudjono. 2009. Pengantar Statistic Pendidikan. Jkarta: Pt. Rajagrafindo Persada.

Snow, C. 2002. Reading for understanding: Toward a research and development program in reading comprehension. Arlington, VA: RAND. 